\title{
Church as heterotopia
}

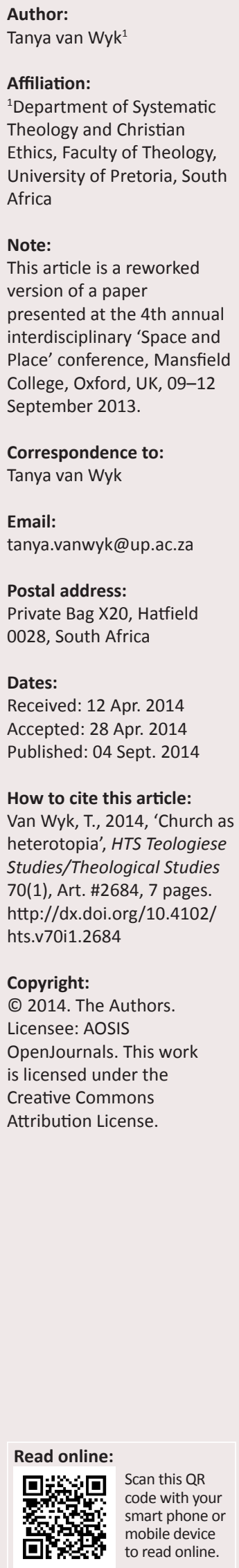

This article reflects on an ecclesiastical institution as a spatial panoptic structure which domesticates representational space as a hierarchy of power devoid of a sensitivity for the 'human Other' (Autrui). The notion of heterotopia is promoted to deconstruct spatiality and linearity (time) as theological binary concepts. Being church as heterotopia does not deny the desire for the utopian dimension in religious thinking but holds on to utopian thinking amidst adversity and diversity. Therefore the concept of heterotopia is used to describe reconciliatory diversity, which is characteristic of an inclusive postmodern church which is a space where unity is not threatened by diversity, where the one is not afraid of the Other.

\section{The challenge: The Church, diversity, and power Linearity and spatiality as binary concepts from a theological perspective}

Postmodernity has once again challenged the church to give responsible expression to the ecclesial truism of being one amidst diversity. The realisation of this unity is seen as a future endeavour or an accomplishment of the future. The Christian church, however, considers itself as a witness of Jesus Christ as God's manifestation in the world. As such it is part and parcel of the world. Being church in the world implies a 'neue Wirklichkeit der Weltgeschichte' (Barth 1959:815). The church exists for the world - not in the sense of a 'second Christ' - but in the sense that the church represents the love of Christ in the world (Barth 1959:883).

According to the South African systematic theologian, Johan Buitendag, ${ }^{1}$ non-linearity has become the language of postmodernity (Buitendag 2003a:1068). In an article about the contribution of the theologian Karl Heim to understand 'time' and 'space', Buitendag (2002b:291-304, 2003b: 15-28) argues that 'time' and 'space' function as primary elements of understanding reality. To be able to communicate postmodernity (non-linear language [thinking]), 'time' and 'space' need to be deconstructed. In the past decade, Buitendag (cf. 2002b:640-655) has given much attention to the importance of 'time' and 'space' in Systematic Theology, with special emphasis on the relationship theology-science and its bearing on the ethical decisions of believers. Being church in the world is not an invisible, future accomplishment. Therefore the deconstruction of 'time' and 'space' also need to be applied to ecclesiology. In this article the notion of heterotopia is suggested and utilised to deconstruct spatiality and linearity (time) as theological binary concepts, in an attempt to answer the postmodern challenge to the church of giving responsible expression to being one amidst diversity. ${ }^{2}$

In his book, Ecclesiology and postmodernity: Questions for the church in our time, Gerard Mannion (2007:ix) discusses the in-limbo situation the church finds itself in after the great ecumenical conference - that of Vatican II. It was the objective of this 4-year-long discussion to help the church - in this case the Roman Catholic Church - how to live the church's unity amidst diversity. Mannion (2007:xii)) refers to Karl Rahner who described the single task of the church as demonstrating that God is love (Deus carita est) in all its internal and external relations.

The 'single' challenge then is linked to a 'single' problem - that of how to 'be' church in the third millennium. This problem rests almost solely on the church's struggle with diversity.

The early apostles had to make a choice with regard to the constitution of the church. This is seen in the oldest part of the canon of the church, the apostle Paul's first letter to the Thessalonians, written in 50-51 AD (Malherbe 2013:19; cf. Van Aarde 2005:21-22). It is reported that 'the Word of God' rippled outwards (exēchētai) (1 Th 1:8) by the 'power of the Holy Spirit' (en dunamei kai en pneumati tōn hagiō) and that this 'dynamic' motivated Paul towards proclaiming the Gospel (1 Th 1:5). This took place in the midst and in spite of opposition (1 Th 1:5), rejection and strife due to opposing opinions. The apostles thus faced two choices: Does 'being church' imply a choice

1.In recognition of a time in which professor Johan Buitendag provided an academic space.

2.For a Trinitarian development of the notion of heterotopia see Van Wyk (2013). 
for love, faith, and hope (1 Th 1:3), based on the inclusive example of Jesus (mimetai)? Or does 'being church' mean a choice for institutionalised genealogy, which could either mean the church is the spiritual Israel, or the continuation of the biological Israel? In essence, when could one be considered to be part of the church and when not? The problem of the church with regard to inclusivity and exclusivity was a problem since the apostle's early proclamation of the Gospel. Today, after more than a decade into the third millennium after the start of the apostolic proclamation, this problem is not only more intense, but also more complex. From a Western cultural viewpoint, this debate about unity and diversity in the church is closely linked to the concepts linearity, spatiality and binarity.

Being church unfolds in space and time - in time over more than 2000 years and in specific spaces far beyond the boundaries of Palestine. According to Foucault ([1967] 1984:46-49), linear time was desacralised in the 19th century. Space however was not. The fact that 'heaven' and 'earth' are still a spatial factuality for so many people, confirms Foucualt's observation (Foucault [1967] 1984). Reading literally, the New Testament reports that the 'end' will dawn when 'the Gospel of the Kingdom of God' is proclaimed to 'all nations' in the 'whole world' (Mt 24:14). In today's ecumenical world the Gospel has spread to the 'whole world', but the 'end' has not dawned and diversity of people, domesticated in different spaces, has caused more underlying tension. If 'end' with regard to space in a 'global village' can no longer be interpreted biblical-theologically in a literal sense, and 'linearity' does not denote the time span of being church anymore, how is the dialectic between unity and diversity with regard to the church manifested in a responsible manner, but more importantly, manifested in such a way that it will lead the church to 'doing differently', and even more importantly, that it does not 'displace' reconciling diversity to an utopian concept that would realise sometime and somewhere in the future, for example as something to be realised at the so-called 'end of time', or being dismissed as an utopian 'fantasy'.

'Utopia thinking' (cf. Saage 1997) however does not result in spatial transcendence or the transcendence of linearity by means of 'fantasy-thinking' (cf. Müller-Fahrenholz 2000). Utopianism is not the solution to the problem of a postmodern church and does not address the dialectic between unity and diversity:

\footnotetext{
... developments in postmodern theory (especially questions of 'post-foundationalist' epistemologies) have contributed to the breakdown of former barriers between evangelical, mainline, and Catholic communities. Postliberalism - a related 'effect' of postmodernism - has engendered anew, confessional ecumenism wherein we find non denominational evangelical congregations, mainline Protestant churches, and Catholic parishes all wrestling with the challenges of postmodernism and drawing on the culture of postmodernity as an opportunity for rethinking the shape of churches. (Smith 2006:9)
}

At the heart of this dialectic tension is binary coding, which can be traced back to Plato's dualism (see Elbow
1993:51-78). Binary thinking has an effect on how we think about time (linearity) and space (spatiality), because distinctions are made between 'now' and 'hereafter' and also between 'here' and 'there'. With regard to the church, this leads to, among other things, the distinction between the so-called 'visible' and 'invisible' church. ${ }^{3}$ According to binary thinking, the 'visible' church is the phenomenon church as it appears 'now'. Seen from such as position church unity cannot be a reality 'now', simply because of the diversity of humanity, which according to this argument makes unity impossible and therefore displaces it to some sort of utopian future. The 'invisible' church refers to the understanding that the church is already one, because of an abstract conceptualisation of a mutual belief in God. According to this argument, church unity does not have to be realised 'here' and 'now', because all believers are 'invisibly 'one'. This binary thinking sidesteps the gospel's imperative to be one, but even more importantly, it provides the grounds for homogenising and heterogenising, because the challenge of dealing with 'otherness' is seen as an impossible, insurmountable task. In dealing with diversity and otherness, the church then becomes a panoptic structure (space).

\section{The church as panoptic structure: A hierarchy of power devoid of a sensitivity for the human Other (Autrui)}

It was the English philosopher and social theorist Jeremy Bentham who first designed the architectural form of 'a perfect modern prison' - a panopticon - a circular building with a central watchtower from where prisoners (or factory workers, scholars, patients, troops, office workers, apartment inhabitants) could be observed fully while they know they are being watched, but they cannot see who is watching them, that is, the institutional control remains invisible (Bentham 1995:29-95). The precise design of Bentham's panopticon was never built. However, Foucault (1995:198; cf. Rainbow [1984] 1991:206-213) maintained that the idea underlining the design - 'a sentiment of invisible omniscience' (Lang 2004:53) wherein the 'prisoners' keep on existing as if the observation is constant and ever-present - was internalised by each and every modern 'institution'. Bentham (1995:30) described it as a 'new mode of obtaining power of mind over mind, in a quantity hitherto without example' (cf. Van Aarde 2012:4 of 11).

Because of the very fact that 'subjects' are constantly aware of this, albeit the invisible panoptical societal structure, subjects are able to police themselves (Bentham's [1995] original intention). This process which starts with 'observation' (subjects are aware that they are being observed) and leads to 'control' (subjects being aware that the observation's function is control), leads to subjects further conforming to the observation or control and then being 'normalised',

3.This refers to the Protestant Reformation's distinction between the 'visible' church and the 'invisible' church which was a reaction against the Roman Catholic Church's understanding of church unity. According to that understanding, unity is bound to understanding of church unity. According to that understanding, unity is bound to
people and places, that is, the Pope and Rome (see Calvin [1541] 1973's Institutes, people and
Book IV.I.7) 
and by then 'examining' themselves according to and on the grounds of the 'norm'. Foucault (1982:778) used 'panopticon' as broad metaphor, to refer to modernity which imperceptibly regulates people's lives in a heteronormative way: mad versus normal, sick versus healthy, homosexual versus heterosexual (Van Aarde 2012:4 of 11; my translation).

Foucault exposes the patterns of power in historical and contemporary societies. Power reifies people by objectifying people, which is to subjectify people. A person becomes an object in relation to someone else due to firstly, being controlled by someone else and being made reliant on that person. Secondly, a person becomes an object in relation to someone else because as an 'object' a person becomes fixed to the identity assigned to you as your identity on your behalf. Within the panopticon - and because of an amount of selfknowledge - all of this happens while you are fully aware of it taking place (Foucault 1982:781). A person becomes embodied in those patterns of life which they are subjected to as an object - others become the judge of your thoughts and practices. This is the process of objectifying and forms the context for the contemporary Western way of governance. In a 'panoptical' manner the objectifying does not visibly manifest as governance by way of violence or coercive power that is visible in violent or explicit tactics of coercive acts. Rather it manifests in the creation and then the perpetuation (constitution) of government and the exercise of discipline by government to the extent that a person lets him- or herself be governed by this process. In liberal democracy 'offenders' are punished in a less brutal way, so that they are in fact punished more effectively.

In the church, imperceptibly, discipline has moved from an external 'hard' authority to a control over 'people's bodies and 'hearts' (the Platonic 'soul'). Heteronormative master narratives relating to health and/or pathologising, racism, sexuality and gender exert this control. But what is more distressing than the church trying to exercise power in this manner, is that people (within the church, the church itself) accept it as 'normal' and resign themselves to it. Within this panoptic structure a hierarchy of power, devoid of a sensitivity for the human Other, is characteristic of the space of the institutional church.

\section{Transcending linearity and spatiality as theological binary concepts}

With the help of Foucault's concept of heterotopia, an attempt is made here to transcend the remnants of binary thinking in ecclesiology. This endeavour needs to be understood against the background of the contribution of Henry Lefebvre ([1974] 1991:26). Lefebvre understands space as 'a social product'. ${ }^{4}$ He sets his understanding of the concept of 'space' apart from an a priori theoretical category. Rather, he understands space as a category of existential experience (cf. Jungkeit 2012:15). Lefebvre ([1974] 1991:5) goes as far as stating that Jacques

4.Lefebvre focused on the architectural layout of cities and roads, national boundaries, households and social codes that are represented by it. Jungkeit (2012:15) applies these insights to theology.
Derrida's interpretation of space has the possibility of getting stuck at a theory of space because he describes space as an epistemological discursive dimension only. This can be seen in Derrida's 'deconstruction of identity' (Lefebvre [1974] 1991:5). Against this, Lefebvre views space as the product of social relations - and he emphasises the dynamics of 'material conditions' that produce space as 'mental ideations' (cf. Jungkeit 2012:5). Lefebvre designs a typology of space that consists of a 'trialectic' (Lefebvre [1974] 1991:35), namely spatial practices, spatial representation and representative spaces. Spatial practices are linked to 'bodily and/or material' involvement when 'bodies inhabit particular spaces.' These practices may seem trivial and static, like walking in a road to and from work every day, yet these practices are complex and are filled with improvisation, based on the many interactions that could take place on that road. With regard to these spatial practices, the focus of spatial representation is on those things according to which people organise their lives, like road and country maps, and time calendars. This results in the practice of trying to control space 'rationally'. With the third category in the trialectic of space, is that of representational spaces.

Lefebvre has two aspects in mind: the internal affect (affection) of the experience of the practice and the organisation of spaces (the first two categories). Here imagination, dreams, memories, anxiety, fear and fantasy are aspects that are the result of the existential relation of people to the material spaces they inhabit (this is in reference to Heidegger's ([1927] 1962) concept of 'Dasein'). In this sense, representational space is 'virtual space' (more or less what Derrida could have illustrated with his concept of 'space' as metaphor). According to Lefebvre ([1974] 1991:45), representational spaces have the ability to make the habitation of certain spaces bearable (the second category) and also to change these spaces when 'virtual spaces' are represented in literature, art and architecture.

David Harvey utilises Lefebvre's typology of space. Against the backdrop of capitalism and economic globalisation Harvey (2000) discusses production and consumption, which he describes as a 'degeneration of utopias.' The question is why people allow themselves to be co-opted in the production and consumption (Harvey 2000:233-235). He coins the concept 'insurgent architects', which refers to people who are able to make a difference in interrelational relationships. In this regard Harvey relates to Lefebvre's ([1974] 1991) articulation of utopia criticism in anti-binary thinking:

By seeking to point the way towards a different space, towards a space of a different social life, and of a different mode of production, this project straddles the breach between science and utopia, reality and ideality, conceived and lived. It aspires to surmount these oppositions by exploring the dialectical relationship between 'possible' and 'impossible', and this both objectively and subjectively. (p. 60)

Transcending linearity and spatiality as theological binary concepts (for the church to be able to cope with diversity) 
entails anti-binary thinking. In this regard, the anti-binary thinking of Lefebvre ([1974] 1991, 2003) and that of Harvey $(1990,2000)$, firmly rests on the philosophy of Martin Heidegger and Jacques Derrida. In Heidegger's Being and time (Sein und Zeit) ([1927] 1962:247-250), he argues that René Descartes (1596-1650)'s ontology (study of 'being') is unacceptable because it does not do justice to the sensory aspect of 'being'. In Cartesian modernistic, rational thinking (Heidegger [1927] 1962:247-250), the world is objectified to the extent that existing (being) in the world (Dasein) is not taken into account (cf. Elden 2004:821-845; Davidson 2009:223-224). For Descartes, 'time' and 'space' is 'only in my head' (cogito ergo sum). Heidegger argues there is also a 'being' in time and space 'outside of my head', that is, outside myself (my own thoughts). But, even though you 'step' outside yourself, you are still restricted to your own 'place', due to your own creatureliness (cf. Heim 1946:50). Derrida (cf. Blanchot \& Derrida [1996] 2000), is therefore of the opinion that Heidegger's paradigm with regard to spatiality (space) is 'heterogeneous' and Descartes's is 'homogeneous'. If space is heterogeneous, it entails that 'space' refers to a 'certain realm of extendedness in which a multiplicity of places, and so of entities, can be located' (Malpas 2006:48). Derrida thus 'deconstructs' Descartes and goes further than Heidegger, and is of the opinion that Descartes's point of view leads to 'imaginary ambiguity' being established in 'spatial metaphors' and this in turn has social consequences. For example, when a person is displaced in real life, this displacement (according to Cartesian thinking) will be observed as a purely abstract process (Davidson 2009:223). A 'deconstruction' of 'metaphysical architecture' is needed, so that marginalisation and displacement as 'real practices', can be evaluated (Wigley 1995; cf. Hooper 2002:77, fn., 22). This can be done by way of utopia criticism.

\section{Heterotopia and utopia criticism \\ Holding on to utopian thinking (versus anti-utopia and dystopia) amidst adversity and diversity}

It was the opinion of Ricoeur that positive change in a specific context be described with the help of the concept 'utopia' which literally refers to 'no place'. In this sense Ricoeur meant that ideology is the opposite side of 'utopia' and that ideology has become the West's auto narrative - referring to progress, freedom and democracy (Ricoeur 1986:16). In this narrative there is no 'space' for those on the outside, on the margins those with 'no place'. It is 'here' where the 'imaginary power of utopia' can open up new vistas for thinking new and differently about society, power, and religion - basically in the sense of a 'fantasy of the alternative' (Ricoeur 1986:16). This does not mean that utopia is considered abstractly - in other words - that the 'no space' cannot be realised (Jantzen 2007:189).

In this sense Richard Saage makes a distinction (in German) between utopia ('Utopie') and the utopian ('das Utopische'). The first one refers to plans and/or ideas to bring about an emancipation from hunger and misery (Saage 1997:133, 196; cf. Albert 2003:87). The second one refers to how an 'Utopist' sees the future realised in the present. This however demands utopia criticism, which is holding on to utopian thinking amidst diversity and adversity. Utopia criticism is not anti-utopian - rather it is dystopian, which paradoxically envisions the realisation of an utopian dimension, while exposing false utopias; that is, being critical towards utopias.

Utopia criticism is present in the 'heterotopian' thinking of Lefebvre ([1974] 1991; 2003) and Harvey (1990, 2000), which is based on Foucault's ([1967] 1984) use of the concept of 'heterotopia'.

'Heterotopia' is an epistemological insight of Foucault ([1967] 1984) and was coined by him in a lecture in $1967^{5}$ in reference to 'space' as place of representation; 'utopia' as 'space' of the future; and fantasy as 'space' that has been sacralised. Foucault endorses the concept 'utopia', but very decisively distinguishes between 'heterotopia' and 'utopia'. 'Heterotopias' are not 'fantasy islands'. Heterotopias are spaces, literally 'other places' that exist. But it is a space of contrast (cf. Foucault [1967] 1984; Post 2010:100), because heterotopian space is not devoid of utopian ideals - that is, it is not anti-utopian. Rather it is a space wherein utopia becomes visible and tangible, real and traceable.

Foucault does not apply the concept to any specific space. Rather, he uses the term in a generic sense and refers to examples of heterotopian space, such as the world or space of a playing child - which is a playful and imaginary space, but at the same time it is a space of tension, with regard to expectation and realisation. Examples of 'adult' heteropian spaces mentioned by him are hospitals, jailhouses, cemeteries and old age homes. Foucault ([1967] 1984) identifies a few categories of heterotopian space. These include ${ }^{6}$ 'crisis space' or 'marginalised space' for a social condition which at some time becomes unacceptable (old age homes) and 'space of deviation', like penitentiaries or psychological institutions where people with 'pathology' are removed from 'normal space'. It also includes 'concrete space', where different meanings are awarded to a place by different groups (like a cemetery). Heterotopian space furthermore includes 'spaces of ambiguity' and 'spaces of paradoxes'. Foucault ([1967] 1984:47-48) specifically refers to ancient Eastern gardens, which fulfil a social role and are depicted in tapestries as a micro-cosmos. Sacred places would fit into this category - and the apostle Paul's understanding of the church ${ }^{7}$ (1 Cor 12 \& Rm 12) (the ekklēsia) as 'body of Christ', a space where, paradoxically 'high' and 'low' of society are tied together, could serve as an example of heterotopian space. A final category of heterotopian space is a space which is

5.This lecture, 'Des Espace Autres (Of other spaces: Utopias and heterotopias)' was published in amended form in 1984 and translated from the French into English by Jay Miskowiec ([1967] 1984:46-49, cf. http://web.mit.edu/allanmc/www/ foucault1.pdf).

6.Not all these categories are discussed here. For a more detailed discussion, see Foucault ([1967] 1984:46-49; cf. Post 2010:101-102)

7.Foucault also does not apply the concept directly to any religious context, such as rituals, nor to religious spaces such as church buildings. However, it opened up and continues to open vistas in and for theology, where 'heterotopia' has been applied by the Dutch theologians Paul Post (2010:110-112) and Kees Doevendans (2004:275-282) to the postmodern architecture of church buildings and by the South African theologian, Rian Venter (2006:201-224), to metropolitan ministry. 
locked up (closed, inaccessible) for some and is unlocked (opened up, accessible) for others. Foucault ([1994] 1998: 175-186) has the Scandinavian sauna in mind. Spaces that exist on the grounds of race and sexual preferences are also examples and the church as an institute would fit into this category if homophobic exclusion of sexual minority groups and/or gender persists and leads to the legitimisation of the refusal to ordain the people on the margins (cf. Van Wyk \& Buitendag 2010:1-9).

The point is that heterotopia denotes for Foucault ([1967] 1984, [1994] 1998) a way of seeing and knowing (epistemology), which in turns influences being (ontology) - the space itself; a space that exists, or rather portrays that things can be different. Not only a space wherein the dream of 'other than the norm' is dreamt - that too. Heterotopia is a space where 'other seeing' is 'other being' - other doing.

\section{Heterotopia as ecclesial space}

Heterotopia as alternative to utopia does not imply a 'deeschatologisation'. Actually eschatology implies very much the re-ordering of values within the ekklësia (Crossan 1998:283284). John Dominic Crossan (1998:265-271) distinguishes between a variety of 'eschatologies' in the 1st-century biblical context. According to him, Jesus' concept of the 'kingdom of God' was imbedded in the context of 'ethical eschatology'. Klyde Snodgras (2008:183) argues that when Jesus states in the parable of the growing seed (Mrk 4:26-29) that the Kingdom of God is like this ...', Jesus regards 'the Kingdom of God' in this parable as a present reality:

Any number of parables could be labeled parables of the present kingdom, and to some degree all the parables presuppose that the kingdom of God is present in the activity of Jesus, even where the kingdom is not explicitly in view ... and must be included in for any holistic view of Jesus' teaching on the kingdom. (Snodgras 2008:179)

The expression 'Kingdom of God' does however not imply the 'end of the world', but rather it means that the promises of the Old Testament (OT) scriptures, especially the prophets, had begun with Jesus' actions and words (Snodgras 2008:179). Louise Schotroff (2006:84-85) also rejects the Western-orientated dualistic eschatology that interprets Jesus' statements about the kingdom of God in a linear way as if the ethical consequences of these statements only have bearing on other-worldly time rather than 'this' one.

Paul's expression 'so that God may be all for all' (1 Cor 15:28) refers back to his discourse on the nature of the church ('God works all for all') (1 Cor 12:6), where he describes the church as the 'body of Christ'. In the transition between 1 Corinthians 12 and 1 Corinthians 13, love is the energy of God and is described as 'the most excellent way' to follow in the ekklessia as body of Christ (1 Cor 12:31b). In his book, Rooted in Christ: Toward a radical ecclesiology, Daniel Izuzquiza (2009:xii, xiv) argues that the expression 'body of Christ' (1 Cor 12) has radical implications for being church and for the communio of being human (Izuzquiza 2009:162-164). It is radical because it is 'rooted in Christ' (Izuzquiza 2009:29). Participation in the risen Christ - the ekklēsia as body of Christ - claims the ethic of love which is and which is to come. Within this body of Christ, there are no binary opposites - it is trans-denominational, that is, boundaries are transcended. This implies that respect for the Other is the conscience of the community of faith. It is not an apocalyptic utopia, but rather an eschatological heterotopia. When eschatological hope in the church becomes a reality here and now, the Other is included unconditionally. The challenge is to transcend binarity. A binary mentality represents a Platonic heritage that is so part and parcel of Western culture that the dangers of it are easily overlooked:

Forms of pluralism are seen as dangerous to the very identity and integrity of the church; therefore, greater and centralized teaching authority and clearer and uniform formulations of truth are seen by some as urgent for the very survival of the church ... [e]ven those of us who can tolerate a certain amount of pluralism often tend to speak of the Christian tradition as homogeneous and value expressions of unity over diversity. Essentialist descriptions of reality and valorising the homogeneous over the diverse seem to be significant features of much Western thought and culture. For it cannot be argued that the dominant tendency in Western metaphysical and theological traditions has been to privilege and valorise unity, harmony, and totality and thereby to denigrate, suppress and marginalize multiplicity, contingency, and particularity. (Duraisingh 2000:680-681)

Appreciation of the individual (particularity) is to give recognition to diversity (multiplicity) in such a way that the human dignity of the Other is respected. Heterotopia functions as 'alternative space' to a narcissistic self-desired utopian space (De Caute 2008:22; Foucault [1994] 1998:175-186).

In the context of the New Testament, Paul's ecclesiastical thinking should be broadly understood against the background of the Graeco-Roman moral philosophers such as Seneca and Epictetus (see Long 2002). According to Epictetus, there are actually only two 'main analogies for life' (Oaks [1993] 2009:49). The one is that of a participant in a banquet hosted by the gods. The other is that of a spectator of the Olympic Games (Enchiridion 15; Dissertationes 2.16.28; Fragmenta 17) (see Epictetus [AD 1-2] 2001).

Paul's reference to the 'church as body of Christ' communicates an intent which is conveyed in both metaphors 'banquet' and 'Games'. The body is an anatomic entity in which diversity is linked in a reconciling manner. In a paradoxical way those members which are regarded as lower on the social ladder are not only considered to be part of the body, but also more important (see 1 Cor 12 \& Rm 12). The same can be said about the performative speech act communicated by the phenomenon Olympic Games. In reality nations and people are in the context of the madness of society in constant war with each other. To idealise a world without conflict - that is to strive for an ideal utopia - is unrealistic. The Games, however, replicate the reality of agonistic competition without killing each other. Instead, through the Games, 
recognition is given for both the winners and the losers, because both are allowed to participate (cf. Van Aarde 2013).

The ecclesia becomes a heterotopia when both space and time are transcended by making hegemony obsolete, and creating space and time for the Other in the here-and-now of this immanent real world. Emmanuel Levinas ([1962] 1996) did not have the church in mind, but what he had to say applies for the church as heterotopia:

Instead of seizing the Other through comprehension and thereby assuming all the wars that this comprehension presupposes, prolongs, and concludes, the I loses its hold before the human Other (Autrui), and, unjustified, can no longer be powerful. (p. 17)

Paul used the metaphor mirror in 1 Corinthians 13:12 to express his view on relational distortion caused by diversity and nurtured by hegemony. He used this metaphor in a contextual framework where he reflects on the church as the 'body of Christ'. His 'heterotypical' way of referring to the church pertains to a transcendence of simplistic Platonic dualism. The living of concrete love constitutes the chord according to which reconciling diversity is portrayed.

The question is whether the institutional church today manifests such a mirror. Maybe the power of the metaphor mirror is more clearly articulated by Harry Potter's heterotypical world (see Rowling [1997] 2000:143-157). In a magic mirror, the boy Harry Potter sees that he and his deceased parents hold on to each other with joy and laughter. The 'mirror of Erised' illustrates the utopia of human desire and dreams. The philosopher Dumbledore remarks: 'It does not do to dwell on dreams, and forget to live' (Rowling [1997] 2000:157). Dumbledore is a sage who creates space and time for the marginalised: the house elves who are slaves of the magicians; the half-breeds, such as the centaur who is out of place with regard to both human and animal kind; the mudblood who is stigmatised because of impure ancestry.

Like Lili Wilkinson's (2012) work 'Nerdfighters, "paper towns", and heterotopia', in which she uses Foucault's mirror metaphor to explain heterotopia with reference to the 'mirror of Erised', this article concludes also with the Harry Potter mythos, dreaming of a church that can become a heterotopia of reconciling diversity.

\section{Acknowledgements Competing interests}

The author declares that she has no financial or personal relationship(s) that may have inappropriately influenced her in writing this article.

\section{References}

Albert, B., 2003, 'Zeit für Zukunft: Vom Einfluss der Zeitvorstellung und der gesellschaftlichen Zeitorganisation auf Zukunftvorstellungen und Lebensperspektiven', Inaugural dissertation zur Erlangung des Grades eines Doktors der Philosophie, Johann Wolfgang Goethe-Universität zu Frankfurt am Main.
Barth, K., 1959, Die Lehre von der Versöhnung, Teilband IV/3.2, in Kirchliche Dogmatik, pp. 815-900, EVZ Verlag, Zürich.

Bentham, J., 1995, The panopticon writings, M. Bosovic (ed.), Verso, London.

Blanchot, M. \& Derrida, J., [1996] 2000, The instant of my death and Demeure: Fiction and testimony, transl. E. Rottenberg, Stanford University Press, Palo Alto, CA.

Buitendag J., 2002a, 'Karl Heim se verstaan van ruimte in die debat tussen die teologie en natuurwetenskap', Verbum et Ecclesia 23(2), 291-304. http://dx.doi. org/10.4102/ve.v23i2.1196

Buitendag J., 2002b, 'Die dans van die Christen: die genealogie van tyd en ruimte in 'n postmoderne samelewing', HTS Teologiese Studies/Theological Studies 58(3), 640-955. http://dx.doi.org/10.4102/hts.v58i3.586

Buitendag, J., 2003b, 'Karl Heim se verstaan van tyd in die debat tussen teologie en natuurwetenskap', Verbum et Ecclesia 24(1), 15-28. http://dx.doi.org/10.4102/ ve.v24i1.308

Buitendag, J., 2003a, 'Die wêreld as gelykenis: 'n Trajek om die middelterm van die "teologie" te vind', HTS Teologiese Studies/Theological Studies 59(4), 1063-1080. http://dx.doi.org/10.4102/hts.v59i4.686

Calvin, J., [1541] 1973, 'Inst. IV.I.7', in J. Calvin, Institutes of the Christian Religion, pp. 1021-1024, 1061, Westminster John Knox Press, Louisville, KY.

Crossan, J.D., 1998, The birth of Christianity: Discovering what happened in the years immediately after the execution of Jesus, Harper, San Francisco, CA.

Davidson, M., 2009, 'Displacement, space and dwelling: Placing gentrification debate', Ethics, Place and Environment 12(2), 219-234. http://dx.doi. debate', Ethics, Place and Envirc
org/10.1080/13668790902863465

De Caute, L., 2008, Heterotopia and the city: Public space in a postcivil society, Routledge, London.

Doevendans, K., 2004, 'De kerk als heterotopie: Aantekeningen bij het kerkgebouw van de vijfde mens', in K. Doevendans \& G. van der Horst (reds.), Het kerkgebouw in het postmoderne landschap, pp. 275-282, Boekencentrum, Zoetermeer.

Duraisingh, C., 2000, Contextual and catholic conditions for the cross cultural hermeneutics, Anglican Theological Review 82(4), 679-701.

Elbow, P., 1993, 'The uses of binary thinking', Journal of Advanced Composition 13(1), 51-78.

Elden, S., 2004, 'Between Marx and Heidegger: Politics, philosophy and Lefebvre's "The production of space"', Antipode 39(1), 821-845.

Epictetus, [AD 1-2] 2001, 'Dissertationes ab Arriano digestae 1.16.20-21', in A.A. Long, Epictetus: A Stoic and Socratic quide to life, pp. 7-38, Department of Classics, University of California, Berkeley, CA.

Foucault, M., [1967] 1984, 'Des Espace Autres ('Of other spaces: Utopias and heterotopias)', transl. J. Miskowiec, Architecture/Mouvement/Continuité October, 1984(5), 46-49, viewed 31 March 2014, from http://web.mit.edu/allanmc/ www/foucault1.pdf

Foucault, M., 1982, 'The subject and power', Critical Enquiry 8, 777-795. http:// dx.doi.org/10.1086/448181

Foucault, M. [1994] 1998, 'Different spaces', in J.P. Faubion (ed.), transl. D. Hurley, Essential works of Foucault 1954-1984, vol. 2: Aesthetics, epistemology, methodology, pp. 175-186, Penguin Books, London. http://dx.doi. org/10.1086/448181

Foucault, M., 1995, Discipline and Punishment, Vintage Books, New York, NY.

Harvey, D., 1990, The condition of postmodernity: An inquiry into the origins of cultural change. Oxford University Press, Oxford.

Harvey, D., 2000, Spaces of hope, University of California Press, Berkely, CA.

Heidegger, M., [1927] 1962, Being and time, transl. J. Macquarrie \& E. Robinson, Blackwell, Oxford.

Heim, K., 1946, Glaube und Naturwissenschaft: Die evangelische Gegenwart, Bd. 4, Furche Verlag, Hamburg.

Hooper, B., 2002, 'Urban space, modernity and masculinist desire: The utopian longings of Le Corbusier', in A. Bingeman, L. Sandres \& R. Zorach (eds.), Embodied utopias: Gender, social change, and the modern metropolis, pp. 55-78, Routledge, utopias: Gen
London.

Izuzquiza, D., 2009, Rooted in Jesus Christ: Toward radical ecclesiology, Eerdmans, Grand Rapids, MI.

Jantzen, G.M., 2007, 'On philosophers (not) reading history: Narrative and utopia' in K. Vanhoozer \& M. Warner (eds.), Transcending boundaries in philosophy and theology: Reason, meaning and experience, pp. 177-190, Ashgate Publishing, Hampshire.

Jungkeit, S.R., 2012, Spaces of modern theology: Geography and power in Schleiermacher's world, foreword by G. Ward, Palgrave Macmillan, New York, NY.

Lang, S.B., 2004, 'The impact of video systems on architecture', PhD dissertation, Hartung-Genre Verlag, Konstanz.

Lefebvre, H., [1974] 1991, The production of space, Blackwell Publishing, Malden, MA.

Lefebvre, H., 2003, The urban revolution, University of Minnesota Press, Minneapolis, MN.

Levinas, E., [1962] 1996, 'Transcendence and height', in A.T. Peperzak, S. Critchley \& R. Bernasconi (eds.), Emmanuel Levinas: Basic philosophical writings, pp. 11-32, Indiana University Press, Bloomington, IN. (Studies in Continental Thought).

Long, A.A., 2002, Epictetus: A stoic and Socratic guide to life, Oxford University Press, Oxford. http://dx.doi.org/10.1093/0199245568.001.0001

Malherbe, A.J., 2013, 'New Testament Ethics and the church today', Restoration Quarterly 55(1), 16-23. 
Malpas, J.M., 2006, Heidegger's topology: Being, place and world, MIT Press, Cambridge, MA.

Mannion, G., 2007, Ecclesiology and postmodernity: Questions for the church in our time, Liturgical Press, Collegeville, MN.

Müller-Fahrenholz, G., 2000, 'Healing the wounds of the nations: Towards a common mission of the churches', HTS Teologiese Studies/Theological Studies 56(2/3), 1009-1023. http://dx.doi.org/10.4102/hts.v56i2/3.1759

Oaks, P., [1993] 2009, 'Epictetus (and the New Testament)', Vox Evangelica 23, 39-56, viewed 05 July 2013, from http://www.biblicalstudies.org.uk/

Post, P., 2010, Voorbij het kerkgebouw: De speelruimte van eenander sacral domein, Uitgeverij Abdij van Berne, Heeswijk.

Rainbow, P., [1984] 1991, The Foucault reader: An introduction into Foucault's thought, Penguin Books, London.

Ricoeur, P., 1986, Lectures on ideology and utopia, G.H. Taylor (ed.), Columbia University Press, New York.

Rowling, J.K., [1997] 2000, Harry Potter and the philosopher's stone, Bloomsbury, London.

Saage, R., 1997, Utopieforschung: Eine Bilanz, Primus Verlag, Darmstadt.

Schotroff, L. 2006, The parables of Jesus, transl. L.M. Maloney, Fortress, Minneapolis, $\mathrm{MN}$.

Smith, J.K.A., 2006, Who's afraid of postmodernism?: Taking Derrida, Lyotard, and Foucault to church, Baker Academic, Grand Rapids, MI.
Snodgras, K., 2008, Stories of intent: A comprehensive guide to the parables of Jesus, Eerdmans, Grand Rapids, MI.

Van Aarde, A.G., 2005, NTW (BTh) 451 Inleiding tot en teologie van die outentieke briewe van Paulus: Studiemateriaal, Departement Nuwe-Testamentiese Wetenskap, Universiteit van Pretoria, Pretoria.

Van Aarde, A.G., 2012, 'Verset teen mag: Die pelgrim se reis in drie "Sondergut" gelykenisse in Lukas 15 en 16', HTS Teologiese Studies/Theological Studies 68(1), Art. \#1032, 11 pages. http://dx.doi.org/10.4102/hts.v68i1.1032

Van Aarde, A.G., 2013, 'Faith as an exceptional religious state of consciousness: A pragmatic-linguistic reading of Romans 12 ', paper presented in memoriam o f Abraham Malherbe, North-West University, Potchefstroom, 01August.

Van Wyk, T., 2013, 'Kerk as heterotopiese ruimte: 'n Trinitariese ekklesiologiese model vir die derde millennium', PhD dissertation, Departement Dogmatiek en Christelike Etiek, Universiteit van Pretoria.

Van Wyk, T., \& Buitendag, J., 2010, 'Die eenheid van die kerk in gedrang', HTS Teologiese Studies/Theological Studies 66(1), Art. \#908, 9 pages, http://dx.doi. org/10.4102/hts.v66i1.908.

Venter, R., 2006, 'Space, Trinity and city: A theological exploration', Acta Theologica 26(1), 201-224.

Wigley, M., 1995, The architexture of deconstruction: Derrida's haunt, MIT Press, Cambridge, MA

Wilkinson, L., 2012, 'Nerdfighters, "paper towns", and heterotopias', Transformative Works and Cultures, suppl. ser. 10. http://dx.doi.org/10.3983/twc.2012.0374 